Article

\title{
Genome Sequencing and Analysis of Trichoderma (Hypocreaceae) Isolates Exhibiting Antagonistic Activity against the Papaya Dieback Pathogen, Erwinia mallotivora
}

\author{
Amin-Asyraf Tamizi ${ }^{1}{ }^{\mathbb{D}}$, Noriha Mat-Amin ${ }^{1} \mathbb{D}$, Jack A. Weaver $^{2} \mathbb{D}$, Richard T. Olumakaiye $^{2}$, \\ Muhamad Afiq Akbar ${ }^{3}$, Sophie Jin ${ }^{2}$, Hamidun Bunawan ${ }^{3, *(D)}$ and Fabrizio Alberti ${ }^{2, *}$ (I)
}

1 Agri-Omics and Bioinformatics Programme, Biotechnology and Nanotechnology Research Centre, Malaysian Agricultural Research and Development Institute Headquarters (MARDI), Serdang 43400, Selangor, Malaysia; aminasyraf@mardi.gov.my (A.-A.T.); noriha@mardi.gov.my (N.M.-A.)

2 School of Life Sciences, University of Warwick, Gibbet Hill Road, Coventry CV4 7AL, UK; jack.weaver@warwick.ac.uk (J.A.W.); richard.olumakaiye@warwick.ac.uk (R.T.O.); sophie.jin@warwick.ac.uk (S.J.)

3 Institute of Systems Biology, Universiti Kebangsaan Malaysia (UKM), Bangi 43600, Selangor, Malaysia; muhdafiq.akbar@gmail.com

* Correspondence: hamidun.bunawan@ukm.edu.my (H.B.); f.alberti@warwick.ac.uk (F.A.)

\section{check for}

updates

Citation: Tamizi, A.-A.; Mat-Amin, N.; Weaver, J.A.; Olumakaiye, R.T.; Akbar, M.A.; Jin, S.; Bunawan, H.; Alberti, F. Genome Sequencing and Analysis of Trichoderma (Hypocreaceae) Isolates Exhibiting Antagonistic Activity against the Papaya Dieback Pathogen, Erwinia mallotivora. J. Fung 2022, 8, 246. https://doi.org/ $10.3390 /$ jof8030246

Academic Editor: Laurent Dufossé

Received: 25 January 2022

Accepted: 26 February 2022

Published: 28 February 2022

Publisher's Note: MDPI stays neutral with regard to jurisdictional claims in published maps and institutional affiliations.

Copyright: (C) 2022 by the authors. Licensee MDPI, Basel, Switzerland. This article is an open access article distributed under the terms and conditions of the Creative Commons Attribution (CC BY) license (https:// creativecommons.org/licenses/by/ $4.0 /)$.

\begin{abstract}
Erwinia mallotivora, the causal agent of papaya dieback disease, is a devastating pathogen that has caused a tremendous decrease in Malaysian papaya export and affected papaya crops in neighbouring countries. A few studies on bacterial species capable of suppressing E. mallotivora have been reported, but the availability of antagonistic fungi remains unknown. In this study, mycelial suspensions from five rhizospheric Trichoderma isolates of Malaysian origin were found to exhibit notable antagonisms against E. mallotivora during co-cultivation. We further characterised three isolates, Trichoderma koningiopsis UKM-M-UW RA5, UKM-M-UW RA6, and UKM-M-UW RA3a, that showed significant growth inhibition zones on plate-based inhibition assays. A study of the genomes of the three strains through a combination of Oxford nanopore and Illumina sequencing technologies highlighted potential secondary metabolite pathways that might underpin their antimicrobial properties. Based on these findings, the fungal isolates are proven to be useful as potential biological control agents against E. mallotivora, and the genomic data opens possibilities to further explore the underlying molecular mechanisms behind their antimicrobial activity, with potential synthetic biology applications.
\end{abstract}

Keywords: biocontrol; fungus; Trichoderma; Gram-negative; Erwinia

\section{Introduction}

Papaya dieback disease (PDD), or bacterial crown rot (BCR), is a bacterial-caused disease that has negatively affected papaya crops (Carica papaya L.) in Malaysia, reducing the national papaya export up to $70 \%$ [1]. Initially, Erwinia papayae was reported to be the causal agent of PDD [2], though later Mat Amin et al. [3] molecularly validated the pathogen to have the closest match to E. mallotivora Goto strain DSM 4565 and this was further supported through genome sequencing [4]. Most of the Malaysian papaya cultivated varieties (cultivars) such as 'Eksotika', 'Sekaki', and 'Setiawan' are highly susceptible to this Gram-negative pathogen [5]. Once infected, water soak symptoms become prevalent on papaya petioles, leaves, and the apical stem, and the tree can succumb to the disease within one to two weeks [5-7]. In addition to physical diagnosis, Mohd Said et al. [8] developed a DNA-based detection method for E. mallotivora to further assist in early detection of the disease and Ramachandran et al. [9] conducted a repetitive element PCR fingerprinting (rep-PCR) study to provide an accurate and rapid identification method on various local E. mallotivora isolates. Currently, there is no effective cure for PDD from the moment the 
symptoms appear on the trees. Hence, farmers rely on preventive measures and good management practices to contain and minimise the spread of the disease to neighbouring trees and plots $[5,10,11]$. Recently, E. mallotivora was reported to be affecting papaya in the Philippines and Indonesia, making this species a pathogen of concern that could affect the papaya industry in the entire Southeast Asia region [7,12]. A similar disease termed as papaya black rot has been recently detected in Japan and the pathogen was characterised to be from the genus Erwinia [13].

Numerous studies have been conducted in recent years to understand the pathogenesis of E. mallotivora and find solutions to curb the disease. About four years after the identification of the pathogen, the draft genome sequence of E. mallotivora was published and this has initiated more research [4]. Wee et al. [14], Hamid et al. [15], Juri et al. [16,17], Abu-Bakar et al. [18], Abu Bakar et al. [19], and Tamizi et al. [20] have conducted in-depth studies to understand the host-pathogen interactions and pathogenicity of E. mallotivora at the molecular level, while Noor Shahida et al. [6] described the infection from a physiological perspective. The use of conventional breeding and genetic engineering to develop new papaya lines that would be resistant to E. mallotivora is still in the research pipelines [21-25]. Nevertheless, the effort to combat the disease should be augmented with other approaches, including the use of effective microorganisms and native microbial biocontrol.

Mat Amin et al. [26,27] discovered several Bacillus spp. from soil to be antagonistic towards E. mallotivora, and this effort has pioneered the search for potential antagonistic microbes against $E$. mallotivora that have been ravaging papaya trees. Later, a biocontrol inoculant containing an undisclosed species of Bacillus sp. known as 'Dieback Buster $95^{\prime}$ was launched and claimed to be highly efficient in the prevention of PDD [28,29]. In addition to these, native endophytic bacteria (NEB) isolated from papaya were reported to be capable of suppressing the growth of E. mallotivora [30,31].

While these potential biocontrols have been isolated from the kingdom of bacteria, fungal species possessing antagonistic effects against $E$. mallotivora remain unexplored. Fungi of the genus Trichoderma have been widely studied for their biological control properties against pathogenic fungi and other bacterial species [32-35]. They are known plant growth-promoting fungi (PGPF), abundant in soil and easily culturable [36,37]. According to Guo et al. [37] and Khan et al. [38], Trichoderma species produced diverse compounds and active metabolites during their interaction with competitors. This makes an effort to single out a potential antimicrobial compound from a particular Trichoderma species relatively challenging. Rush et al. [39] produced a systemic review on Trichoderma bioprospecting which discussed the application of genome technology in screening for natural products and biocontrol compounds. In the present study, we have discovered five Trichoderma isolates that showed antimicrobial activity against the E. mallotivora strain BT-MARDI, of which three were further characterised through genome sequencing to investigate the possible mechanisms behind their antimicrobial properties.

\section{Materials and Methods}

\subsection{Preparation of Pathogen}

The papaya dieback pathogen, E. mallotivora strain BT-MARDI, was obtained from the Biotechnology and Nanotechnology Research Centre, at the Malaysian Agricultural Research and Development Institute (MARDI) in Serdang, Selangor, Malaysia. A stock culture of E. mallotivora was maintained in $15 \%(w / v)$ glycerol at $-80{ }^{\circ} \mathrm{C}$. Working cultures were established by streaking the glycerol stock onto Luria Bertani (LB) agar plates $(10 \mathrm{~g} / \mathrm{L}$ tryptone, $5 \mathrm{~g} / \mathrm{L}$ yeast extract, $10 \mathrm{~g} / \mathrm{L}$ sodium chloride, $15 \mathrm{~g} / \mathrm{L}$ agar) and incubating at $30^{\circ} \mathrm{C}$ for $48 \mathrm{~h}$. Fresh single colonies were then picked and cultured in $50 \mathrm{~mL} \mathrm{LB}$ medium $(10 \mathrm{~g} / \mathrm{L}$ tryptone, $5 \mathrm{~g} / \mathrm{L}$ yeast extract, $10 \mathrm{~g} / \mathrm{L}$ sodium chloride) in a $250 \mathrm{~mL}$ flask, shaking at $180 \mathrm{rpm}$ for $24 \mathrm{~h}$. 


\subsection{Isolation of Antagonist Fungi}

The rhizosphere soil samples were randomly collected from healthy papaya plants (wild and cultivated) at five different locations (Table 1) in Peninsular Malaysia. Then, soil dilution was performed and used to grow culturable fungi, particularly Trichoderma, on potato dextrose agar (PDA) supplemented with selective agents. Briefly, $50 \mathrm{~g}$ of soil sample were diluted in $50 \mathrm{~mL}$ of sterile distilled water. Serial dilution was performed at $1 / 10,1 / 100,1 / 1000$, and 1/10,000. Four hundred microliters of the diluted soil suspension were spread on modified PDA (PDA; $20 \mathrm{~g} / \mathrm{L}$ glucose, $4 \mathrm{~g} / \mathrm{L}$ potato extract, $20 \mathrm{~g} / \mathrm{L}$ agar) medium containing $0.3 \mathrm{~g} / \mathrm{L}$ chloramphenicol, $0.1 \mathrm{~g} / \mathrm{L}$ streptomycin, and $0.02 \mathrm{~g} / \mathrm{L}$ Rose Bengal dye [40]. The plates were incubated at $25^{\circ} \mathrm{C}$ for 3 to 14 days to allow fast and medium-fast growing fungi to appear. The emerging fungal colonies were then purified by single spore isolation [41] and maintained on PDA slants at $4{ }^{\circ} \mathrm{C}$. Long-term storage of fungi was achieved by cutting a $5 \mathrm{~mm}^{2}$ of mycelial agar plug from freshly growing cultures, which was stored in $30 \%(w / v)$ glycerol at $-80^{\circ} \mathrm{C}$.

Table 1. Origin of the soil samples used for the isolation of the fungi identified in this study. The soil samples were collected from wild and cultivated healthy papaya populations in different states (Selangor, Negeri Sembilan, Pahang, and Kedah) of Peninsular Malaysia.

\begin{tabular}{ccc}
\hline Soil Sample ID & Location Site, State & Coordinates \\
\hline Mardi-2018-TK & Tanjong Karang, Selangor & $3^{\circ} 26^{\prime} 27.8^{\prime \prime} \mathrm{N} 101^{\circ} 08^{\prime} 50.1^{\prime \prime} \mathrm{E}$ \\
Mardi-2018-R & Rembau, Negeri Sembilan & $2^{\circ} 34^{\prime} 26.0^{\prime \prime} \mathrm{N} 102^{\circ} 05^{\prime} 48.5^{\prime \prime} \mathrm{E}$ \\
Mardi-2018-P & Raub, Pahang & $3^{\circ} 49^{\prime} 19.3^{\prime \prime} \mathrm{N} 101^{\circ} 50^{\prime} 38.4^{\prime \prime} \mathrm{E}$ \\
Mardi-2018-C & Mardi Serdang, Selangor & $2^{\circ} 59^{\prime} 24.9^{\prime \prime} \mathrm{N} 101^{\circ} 41^{\prime} 49.5^{\prime \prime} \mathrm{E}$ \\
Mardi-2018-BK & Baling, Kedah & $5^{\circ} 40^{\prime} 05.6^{\prime \prime} \mathrm{N} 100^{\circ} 49^{\prime} 47.5^{\prime \prime} \mathrm{E}$ \\
\hline
\end{tabular}

\subsection{Antagonistic Activity of Fungal Isolates against E. mallotivora Strain BT-MARDI}

The antagonistic activity of fungal isolates against $E$. mallotivora was screened in vitro using the agar well diffusion method on PDA plates [31,42,43]. An agar plug $\left(5 \mathrm{~mm}^{2}\right)$ from each five-day old fungal culture was inoculated into $100 \mathrm{~mL}$ potato dextrose broth (PDB; $20 \mathrm{~g} / \mathrm{L}$ glucose, $4 \mathrm{~g} / \mathrm{L}$ potato extract) in $500 \mathrm{~mL}$ flasks and grown for seven days at $25^{\circ} \mathrm{C}$ with agitation at $180 \mathrm{rpm}$. A lawn of E. mallotivora was prepared by spreading $100 \mu \mathrm{L}$ of the E. mallotivora inoculum over the entire agar surface. A hole with a diameter of $6 \mathrm{~mm}$ was punched aseptically with a sterile cork borer and $100 \mu \mathrm{L}$ of the fungal suspension were dispensed into the well. A kanamycin solution $(100 \mu \mathrm{g} / \mathrm{mL})$ and PDB, $100 \mu \mathrm{L}$ of each, were used as the positive and negative controls, respectively. After overnight incubation at $28^{\circ} \mathrm{C}$, the plates were observed for zone of inhibition formation on the E. mallotivora lawn. The experiment was repeated in triplicate for each isolate to record the average diameter of the inhibition zone. The data for fungal isolates exhibiting significant antagonism compared to the positive control was analysed using IBM SPSS Statistics version 28.0.1.1 (14).

\subsection{Genomic DNA Extraction}

Cultures of the three selected fungal isolates, UKM-M-UW RA3a, UKM-M-UW RA5, and UKM-M-UW RA6 (hereafter referred to as RA3a, RA5, and RA6), were set up in $25 \mathrm{~mL}$ of PDB from PDA plates and placed in $250 \mathrm{~mL}$ conical flasks. The fungal cultures were incubated at $25{ }^{\circ} \mathrm{C}$ for $72 \mathrm{~h}$, shaking at $200 \mathrm{rpm}$. The mycelia from the broth were pelleted by centrifugation at $8000 \times g$ for $5 \mathrm{~min}$, and subsequently washed twice with sterile distilled water to remove any residual medium. High molecular weight (HMW) genomic DNA extraction was carried out via cryogenic grinding using a sterile mortar and pestle. Fungal mycelia were ground into a fine powder in liquid nitrogen; thereafter, $200 \mathrm{mg}$ of the powder were transferred aseptically into a microcentrifuge tube for immediate use. A GenElute Plant Genomic DNA miniprep kit (Sigma-Aldrich, Burlington, MA, USA) was used for DNA extraction, following the manufacturer's instructions. HMW genomic DNA was concentrated using ethanol precipitation. Briefly, 1/10 volume of $3 \mathrm{M}$ sodium acetate, 
$\mathrm{pH}$ 5.2, was added, followed by three volumes of $100 \%$ ethanol. Samples were inverted, incubated at $-20{ }^{\circ} \mathrm{C}$ overnight, then spun at $13,000 \times \mathrm{g}$ for $30 \mathrm{~min}$ at $4{ }^{\circ} \mathrm{C}$. Supernatant was decanted, the DNA pellet was air dried, and then resuspended in nuclease-free water (Thermo Fisher, Waltham, MA, USA). Gel electrophoresis ( $1 \% w / v$ agarose gel with $1 \mathrm{X}$ GelRed), a Nanodrop ND1000 (Thermo Fisher, USA), and a Qubit (dsDNA Broad range, Invitrogen, Waltham, MA, USA) were used to assess the concentration (Table S1) and quality of the HMW genomic DNA extracted from the fungal strains.

\subsection{Identification of Fungi Based on Mycelia Morphology, PCR Amplification, and Sanger Sequencing}

Mycelial morphology was originally used to identify the class/genus of the fungal isolates based on the colour of the mycelia and spore characteristics. Subsequently, PCR amplification of target sequences was carried out using purified genomic DNA as a template to identify the fungal isolates of interest, RA3a, RA5, and RA6. PCR was carried out using Q5 High-Fidelity 2X Master Mix (NEB, Ipswich, MA, USA) according to the manufacturer's instructions, using the primers listed in Table S2. The amplicons were purified upon gel electrophoresis ( $1 \% w / v$ agarose gel with 1X GelRed) using the GeneJET PCR purification kit (Thermo Fisher, USA) following the manufacturer's instructions. One hundred nanograms of the purified PCR product was used for Sanger sequencing through Eurofins-GATC, which enabled for the phylogenetic confirmation of the strains. The sequences were trimmed to obtain diagnostic fragments for molecular identification as detailed in Kopchinskiy et al. [44] prior to submission to BLASTN [45].

\subsection{DNA Library Preparation and Sequencing through Oxford Nanopore Technology (ONT)}

Utilising the extracted HMW genomic DNA, preparation of the library was performed using the native barcoding expansion kit (EXP-NBD104 and EXP-NBD114) and the ligation sequencing kit (SQK-LSK109) for multiplex genomic DNA sequencing of the fungal isolates RA3a, RA5, and RA6. NBD01 was used to tag RA3a, NBD02 for RA6, and NBD03 for RA5. The manufacturer's protocol was followed with minor modifications introduced for both DNA repair and end-prep stages, by increasing the incubation time and temperature after washing with ethanol to $15 \mathrm{~min}$ at $37^{\circ} \mathrm{C}$. Furthermore, at the native barcode ligation step, the incubation time and temperature were increased to $30 \mathrm{~min}$ at $37^{\circ} \mathrm{C}$. To enrich DNA fragments of $3 \mathrm{~kb}$ or longer, the Long Fragment Buffer was used for the DNA clean-up. An amount of $1.2 \mu \mathrm{g}$ of each genomic DNA were used for the library preparation, resulting in a final amount of $350 \mathrm{ng}$ of DNA at the end of the adapter ligation and clean-up step. The resulting DNA library containing the sequencing buffer and loading beads were loaded on the primed SpotON flow cell. Nanopore sequencing was performed on MinION (ONT) with a FLO-MIN-106 R9.4 flow-cell (ONT). The MinION (ONT) multiplex sequencing reaction was run for $18 \mathrm{~h}$.

\subsection{Genome Assembly and Error Corrections}

A de novo strategy was employed for sequencing each of the three genomes. The raw data produced by nanopore was base-called and simultaneously demultiplexed using Guppy version 4.4.1 available to ONT users via https:/ / community.nanoporetech.com (accessed on 23 January 2022). The config file used in Guppy was dna_r9.4.1_450bps_hac.cfg, the remaining parameters used were the default settings. Guppy was also used to trim the barcodes from the reads during the base-calling, depositing each genome's reads in a directory as .fastq files. The .fastq files for each read were merged into one .fastq file and used as the input for Flye version 2.8.2 with the nano-raw mode selected, which was used to assemble the draft genomes [46]. The draft assembly was then polished multiple times, by aligning the base-called raw reads in the merged file against the draft genome using Minimap2 version 2.11 [47] before correcting errors using Racon version 1.4.20 [48], where matching bases were assigned a score of 8 and mismatches a score of -6 , with a gap penalty of -8 and a window size of 500. The output from Racon was aligned to the raw 
reads again and the process was repeated three times for each assembly. Further corrections were made using Medaka version 1.2.1 utilising model r941_min_high_g360.

Polishing the genome continued by using Illumina short-read data generated through Apical Scientific Sdn. Bhd. (Seri Kembangan, Selangor, Malaysia). This was done by aligning the Illumina data to the output from Medaka using Bowtie2 version 2.4.2 [49]. Bowtie2 was run with the following settings, $-\mathrm{D}$ (number of attempts at extension before skipping to the next task) 20, $\mathrm{R}$ (number of seeds looked at before moving to the next task) $3,-\mathrm{N}$ (maximum number of mismatches in alignments) 1, -L (length of seed substrings) 20, and -i (interval between seed substrings) S,1,0.50, all other settings were left at the default parameters. Polishing was performed with Pilon version 1.23 [50], the output from Pilon was then re-aligned to the Illumina reads and the draft genome polished again; after Pilon had been run four times, the final output was analysed using BUSCO version 5.0.0 [51], comparing the three genomes against the Hypocreales_odb10 database. Unless specified above, parameters within programs were left at their default setting.

\subsection{Genome Annotations}

Functional annotation was performed using the Funannotate version 1.8.3 pipeline [52]. Funannotate was also able to clean (remove small repetitive contigs by using minimap2 or mummer) and perform mask repeats (softmasking of low complexity and short period tandem repeats using tantan). The prediction of functional elements was done using a seed species of Verticillium longisporum and the BUSCO Sordariomycetes database; the minimum number of training models required was dropped to 100, and the Optimize Augustus setting was turned on. Funannotate predict uses AUGUSTUS, snap, GlimmerHMM, and tRNAscan-SE in order to predict genes for proteins and tRNAs, as well as other programs to generate the inputs for those mentioned above and the final outputs. The predictions were then run through Phobius [53] and AntiSMASH [54], contained within Funannotate. Finally, the annotation function was used to create the final genomes. BUSCO was run again to look at the predicted proteins generated, once again using the Hypocreales_odb10 database. All parameters not mentioned above were left on their default setting within the software package.

CMscan [55] was used with StructRNAfinder [56] for screening the presence of potential non-coding RNA. The Rfam database [57] was used as the input database for StructRNAfinder with the default parameters.

\subsection{Comparative Genomics and Phylogenomic Analysis}

Pairwise genomic similarities between our isolates with addition of nine additional genomes from other Trichoderma spp. (obtained from the NCBI database) were calculated using FastANI, with assembled genomic sequences as input [58]. The pairwise genomic similarities were then visualised using the Intervene Shiny package [59]. Next, to reconstruct the phylogenomic association between several strains of Trichoderma spp., single-copy orthologous proteins were first identified from the predicted proteome sequence via OrthoFinder v2.2.7 with default settings [60]. Then, amino acid sequences from single-copy orthologous proteins identified were aligned using MAFFT [61]. This alignment was then used for maximum likelihood phylogenomic tree reconstruction via the IQ-TREE program, using the JTT+F+G4 model and 1000 ultrafast bootstrap replications [62]. iTOL was used for phylogenomic tree visualisation [63]. Finally, OrthoVenn2 web server was used for comparison of orthologous proteins from our isolates with the predicted proteome as input [64].

\section{Results}

\subsection{Antagonism of Fungal Isolates against E. mallotivora Strain BT-MARDI}

In this study, a total of 128 filamentous fungal and yeast isolates were cultured from five soil samples collected in various locations in Peninsular Malaysia (Table 1). Out of these, only 17 fungal isolates that grew mycelia in less than 14 days on PDA plates- 
species putatively belonging mainly to the genera Trichoderma, Fusarium, Aspergillus, and Penicillium based on morphological identification-were observed to have antagonistic activity against E. mallotivora strain BT-MARDI. According to plate-based inhibition assays, five fast-growing fungal isolates that required less than seven days to form a full mycelial lawn on PDA plates were confirmed to exhibit visible antagonism (Figure 1) and selected for further analysis. The taxonomic affiliation of these isolates was originally deduced based on mycelium morphology, with all five strains, or isolates, putatively assigned to the genus Trichoderma (Figure 2). All isolates exhibited inhibition of the growth of E. mallotivora (Table 2). Based on the Tukey's test, RA5, RA6, and RA3a had a significant antagonistic activity when compared to the positive control (kanamycin) (Figure 3).

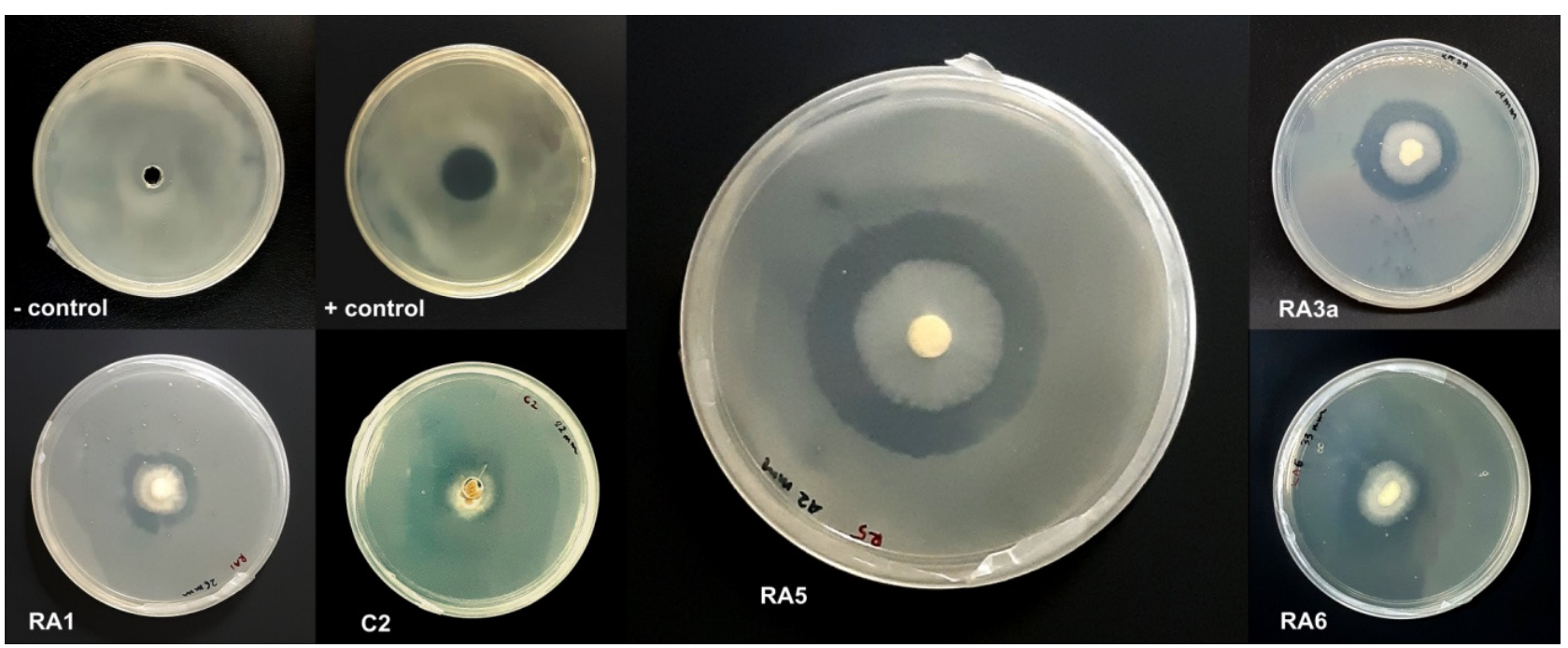

Figure 1. Plate-based growth inhibition assays of E. mallotivora through well diffusion method. All fungal isolates displayed notable growth inhibition zones. Potato dextrose broth (PDB) and kanamycin were used as the negative and positive controls, respectively.

Table 2. Antagonistic potential of the Trichoderma isolates against E. mallotivora. The negative (-) control consists of $100 \mu \mathrm{L}$ of PDB, the positive (+) control of $100 \mu \mathrm{L}$ of kanamycin $(100 \mu \mathrm{g} / \mathrm{mL})$.

\begin{tabular}{|c|c|c|c|c|c|c|c|}
\hline \multirow{3}{*}{ Treatment } & \multicolumn{5}{|c|}{ Diameter of Inhibition Zone (mm) } & \multirow{3}{*}{$\begin{array}{l}\text { Fungal Genus } \\
\text { (Based on } \\
\text { Morphology) }\end{array}$} & \multirow{3}{*}{$\begin{array}{l}\text { Origin of the } \\
\text { Fungal Isolate }\end{array}$} \\
\hline & \multicolumn{3}{|c|}{ Replicate } & \multirow{2}{*}{ Mean } & \multirow{2}{*}{$\begin{array}{l}\text { Standard } \\
\text { Deviation }\end{array}$} & & \\
\hline & 1 & 2 & 3 & & & & \\
\hline - control & 0 & 0 & 0 & 0 & 0 & - & - \\
\hline+ control & 17 & 17 & 17 & 17.0 & 0 & - & - \\
\hline $\begin{array}{l}\text { Isolate } \\
\text { UKM-M-UW RA5 }\end{array}$ & 42 & 39 & 42 & 41.0 & 1.73 & Trichoderma & $\begin{array}{l}\text { Rembau, Negeri } \\
\text { Sembilan }\end{array}$ \\
\hline $\begin{array}{l}\text { Isolate } \\
\text { UKM-M-UW RA6 }\end{array}$ & 33 & 26 & 34 & 31.0 & 4.36 & Trichoderma & $\begin{array}{l}\text { Rembau, Negeri } \\
\text { Sembilan }\end{array}$ \\
\hline $\begin{array}{l}\text { Isolate } \\
\text { UKM-M-UW RA3a }\end{array}$ & 34 & 28 & 27 & 29.7 & 3.79 & Trichoderma & $\begin{array}{c}\text { Rembau, Negeri } \\
\text { Sembilan }\end{array}$ \\
\hline $\begin{array}{l}\text { Isolate } \\
\text { UKM-M-UW RA1 }\end{array}$ & 20 & 23 & 26 & 23.0 & 3.0 & Trichoderma & $\begin{array}{c}\text { Rembau, Negeri } \\
\text { Sembilan }\end{array}$ \\
\hline $\begin{array}{l}\text { Isolate } \\
\text { UKM-M-UW C2 }\end{array}$ & 15 & 22 & 23 & 20.0 & 4.36 & Trichoderma & Serdang, Selangor \\
\hline
\end{tabular}




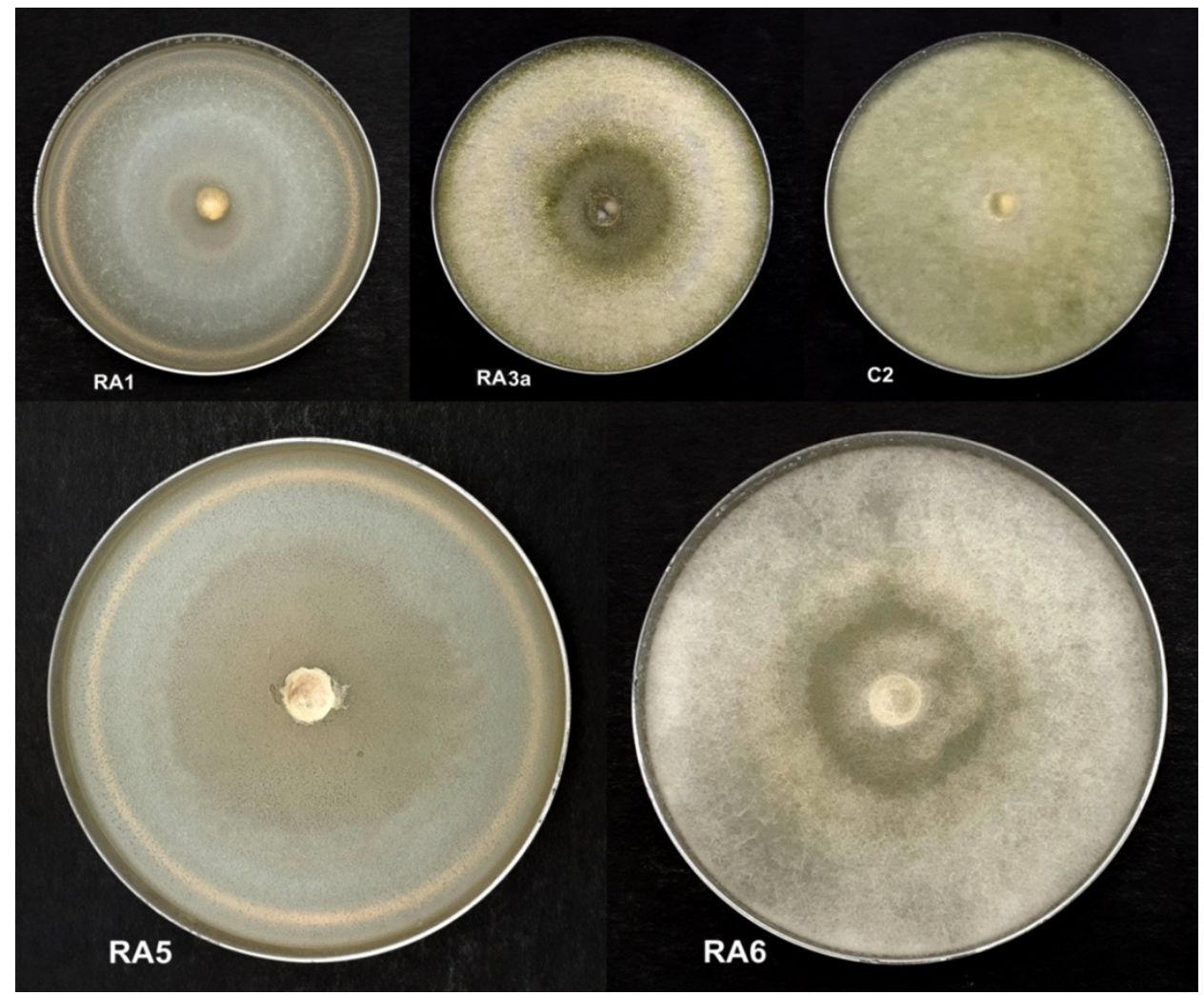

Figure 2. Physical morphology of the five fungal isolates RA1, RA3a, C2, RA5, and RA6 cultured on PDA plates growing filamentous mycelia across the agar after five days of incubation. All isolates show the morphological characteristics of Trichoderma-white filaments and, as the isolates mature, faint olive-green spores.

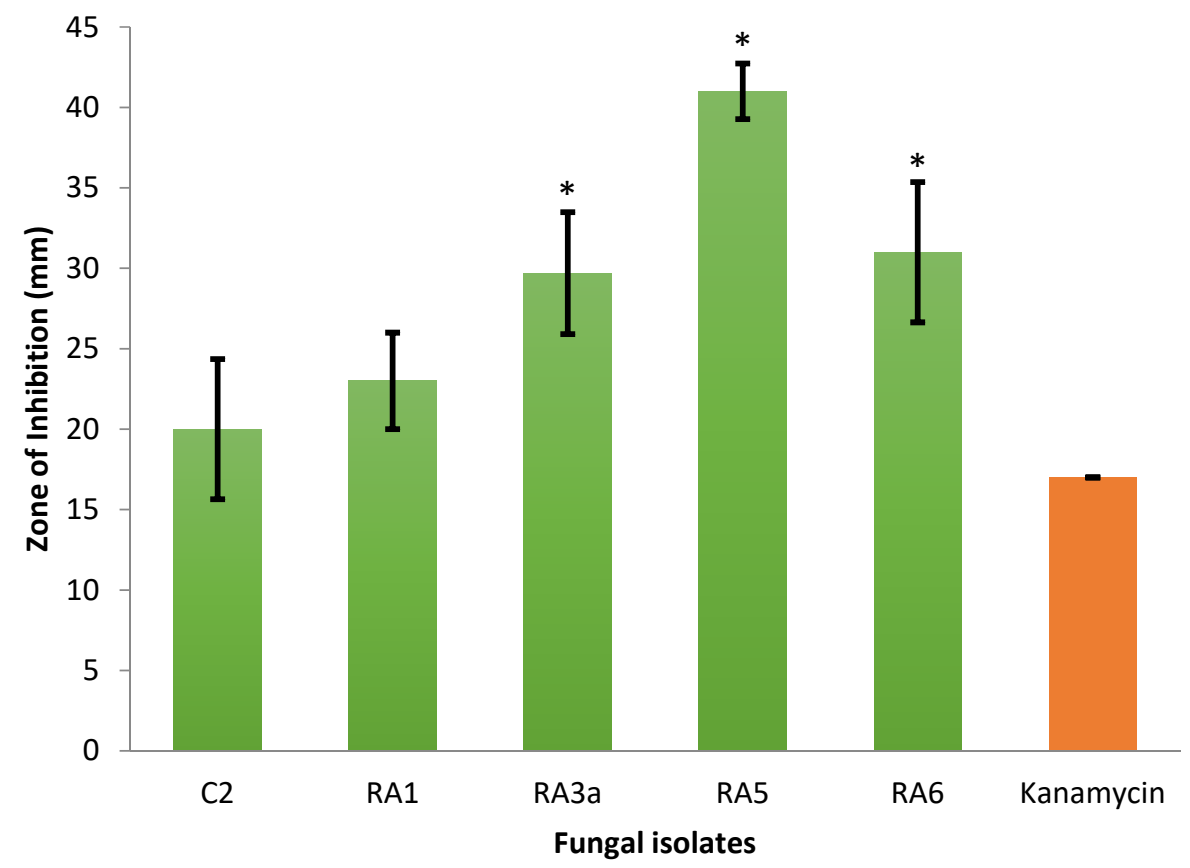

Figure 3. In vitro screening for antagonism of five fast-growing fungal isolates (Trichoderma spp.) against E. mallotivora 'BT-MARDI' using the agar well diffusion method. Values are means of triplicates and the standard deviations are indicated by the error bars. Isolates with significant antagonism (compared to kanamycin) were determined using the Tukey's test $(\mathrm{N}=18, p<0.05)$ and are marked with an asterisk $\left(^{*}\right)$. 


\subsection{Genomic DNA Extraction}

High molecular weight (HMW) genomic DNA extraction was performed on the three fungal isolates, RA3a, RA5, and RA6, that showed significant inhibition on E. mallotivora. To improve the genomic DNA yield and quality, the extracted fungal DNA was subjected to ethanol precipitation and resuspended in $35 \mu \mathrm{L}$ of nuclease-free water. The purity and concentration of the DNA was assessed with a Nanodrop ND1000 (Thermo Fisher, Boston, MA, USA) and Qubit (dsDNA Broad range, Invitrogen, Boston, MA, USA), with all preparations yielding more than $100 \mathrm{ng} / \mu \mathrm{L}$ HMW DNA according to Qubit readings (Table S1). The HMW DNA was further visualised via agarose gel electrophoresis (Figure S1). Overall, these analyses proved that the HMW DNA extracted from the three isolates was suitable to be sequenced through Oxford nanopore and Illumina whole-genome sequencing.

\subsection{Molecular Identification of Strains}

The three fungal isolates RA3a, RA5, and RA6 were identified through PCR amplification and Sanger sequencing of three DNA barcodes [65]: internal transcribed spacer (ITS) [66], translation elongation factor 1 alpha (tef1) gene [67] and RNA polymerase B subunit II ( $r p b 2)$ gene [68]. Amplification of each sample yielded a single DNA fragment, the sequence of which was analysed through BLASTN [45]. The sequencing of the ITS marker allowed us to confidently assign all three fungal isolates to the Trichoderma genus. Further sequencing of the tef1 and $r p b 2$ genes enabled us to identify all three fungal strains to be from a single species, T. koningiopsis (Table 3).

Table 3. Molecular identification of the three fungal isolates RA3a, RA5 and RA6 based on Sanger sequencing of the three DNA barcodes ITS, Tef1 and Rpb2.

\begin{tabular}{|c|c|c|c|c|c|}
\hline Isolate & Locus & $\begin{array}{l}\text { Closest Match } \\
\text { Organism }\end{array}$ & $\begin{array}{l}\text { NCBI Accession } \\
\text { Number }\end{array}$ & Coverage $(\%)$ & Identity (\%) \\
\hline \multirow{3}{*}{ UKM-M-UW RA3a } & ITS & $\begin{array}{c}\text { Trichoderma sp. strain } \\
\text { ZMQRS9 }\end{array}$ & MT446202.1 & 100 & 99.83 \\
\hline & Tef1 & $\begin{array}{c}\text { Trichoderma koningiopsis } \\
\text { strain LESF360 }\end{array}$ & KT278986.1 & 100 & 99.65 \\
\hline & $R p b 2$ & $\begin{array}{c}\text { Trichoderma koningiopsis } \\
\text { isolate Tkois1 }\end{array}$ & MT081443.1 & 100 & 99.77 \\
\hline \multirow{3}{*}{ UKM-M-UW RA5 } & ITS & $\begin{array}{l}\text { Trichoderma koningiopsis } \\
\text { strain 18ASMA001 }\end{array}$ & MT520621.1 & 100 & 100 \\
\hline & Tef1 & $\begin{array}{c}\text { Trichoderma koningiopsis } \\
\text { strain VSL155 }\end{array}$ & MT058870.1 & 100 & 99.33 \\
\hline & $R p b 2$ & $\begin{array}{c}\text { Trichoderma koningiopsis } \\
\text { isolate Tkois1 }\end{array}$ & MT081443.1 & 100 & 99.60 \\
\hline \multirow{3}{*}{ UKM-M-UW RA6 } & ITS & $\begin{array}{l}\text { Trichoderma koningiopsis } \\
\text { strain 18ASMA001 }\end{array}$ & MT520621.1 & 100 & 100 \\
\hline & Tef1 & $\begin{array}{c}\text { Trichoderma koningiopsis } \\
\text { strain LESF360 }\end{array}$ & KT278986.1 & 100 & 100 \\
\hline & $R p b 2$ & $\begin{array}{c}\text { Trichoderma koningiopsis } \\
\text { isolate Tkois1 }\end{array}$ & MT081443.1 & 100 & 100 \\
\hline
\end{tabular}

\subsection{Genome Sequencing}

The genomic DNA of the three fungal isolates, RA3a, RA5, and RA6, were sequenced using a combination of Oxford nanopore and Illumina whole-genome sequencing. This generated a significant quantity of both long-read and short-read data which gave a high degree of coverage for each of the three genomes. From the nanopore data, after barcodes had been separated and trimmed, we had generated an estimated 3,176,623,257 bases for strain RA3a, 3,973,025,475 bases for RA5, and 2,406,065,838 bases for RA6. This was complemented by the Illumina sequencing which produced 3,352,912,241 bases for RA3a, and 3,365,209,722 and 2,697,750,185 for RA5 and RA6, respectively. The final draft genome 
sizes for each organism were as follows: RA3a $36.53 \mathrm{Mb}$, RA5 36.48 Mb, and RA6 36.47 Mb. This is consistent with the size of other Trichoderma genome assemblies which tend to be 31-40 Mb in size [69]. As shown in Table 4, the genomes contain 14 (RA3a), 11 (RA5), and 13 (RA6) contigs, the majority of these contigs may be putatively assembled at the chromosome level. Closely related species of Trichoderma have seven chromosomes [70], and our assemblies also included the mitochondrial DNA.

Table 4. Details of genome assembly statistics of the three Trichoderma isolates RA3a, RA5, and RA6.

\begin{tabular}{lccc}
\hline \multicolumn{1}{c}{ Parameter } & RA3a & RA5 & RA6 \\
\hline Number of contigs & 14 & 11 & 13 \\
Total contigs length & $36,531,570$ & $36,477,170$ & $36,470,223$ \\
Mean contig size & $2,609,397.86$ & $3,316,106.36$ & $2,805,401.77$ \\
Contig size first quartile & $1,043,387$ & $3,650,583$ & 981,951 \\
Median contig size & $2,049,512$ & $3,895,316$ & $3,855,011$ \\
Contig size third quartile & $5,555,030$ & $6,876,866$ & $5,268,312$ \\
Longest contig & $6,903,293$ & $6,995,056$ & $6,877,006$ \\
Shortest contig & 6075 & 6406 & 5219 \\
Contigs > 500 nt & $14(100 \%)$ & $11(100 \%)$ & $13(100 \%)$ \\
Contigs > 1K nt & $14(100 \%)$ & $11(100 \%)$ & $13(100 \%)$ \\
Contigs > 10K nt & $13(92.86 \%)$ & $10(90.91 \%)$ & $12(92.31 \%)$ \\
Contigs > 100K nt & $11(78.57 \%)$ & $8(72.73 \%)$ & $10(76.92 \%)$ \\
Contigs > 1M nt & $10(71.43 \%)$ & $7(63.64 \%)$ & $8(61.54)$ \\
N50 & $5,555,030$ & $5,554,967$ & $3,979,290$ \\
L50 & 3 & 3 & 4 \\
N80 & $2,447,863$ & $3,862,469$ & $3,855,011$ \\
L80 & 6 & 6 & 6 \\
\hline
\end{tabular}

Using BUSCO [71] to assess the genome assemblies for core conserved genes across the order Hypocreales, we were able to generate the results presented in Tables 5 and 6 . Table 5 shows the conserved genes identified within the scaffold of our assemblies and Table 6 shows the conserved proteins identified in the predicted proteome of the annotated genomes of each species. An outline of the predicted non-coding RNA is shown in Table S3, the full set of results from StructRNAfinder are publicly available at https:/ / osf.io/vsbc2/ (Accessed on 17 February 2022).

Table 5. Scaffold BUSCO: dataset Hypocreales odb10 for the genomes of the fungal isolates RA3a, RA5, and RA6.

\begin{tabular}{lccc}
\hline \multicolumn{1}{c}{ BUSCO Scaffold Stat } & RA3a & RA5 & RA6 \\
\hline Percentage BUSCO & $97.7 \%$ & $97.7 \%$ & $97.8 \%$ \\
Complete BUSCO's & 4392 & 4391 & 4394 \\
Complete and single copy BUSCO's & 4378 & 4379 & 4381 \\
Complete and duplicate BUSCO's & 14 & 12 & 13 \\
Fragmented BUSCO's & 20 & 20 & 20 \\
Missing BUSCO's & 82 & 83 & 80 \\
Total BUSCO groups searched & & 4494 & \\
\hline
\end{tabular}


Table 6. Proteins BUSCO: dataset Hypocreales_odb10 for the predicted proteomes of the fungal isolates RA3a, RA5, and RA6.

\begin{tabular}{lccc}
\hline \multicolumn{1}{c}{ BUSCO Scaffold Stat } & RA3a & RA5 & RA6 \\
\hline Percentage BUSCO & $92.3 \%$ & $88.0 \%$ & $87.4 \%$ \\
Complete BUSCO's & 4146 & 3955 & 3927 \\
Complete and single copy BUSCO's & 4137 & 3946 & 3922 \\
Complete and duplicate BUSCO's & 9 & 9 & 5 \\
Fragmented BUSCO's & 108 & 219 & 245 \\
Missing BUSCO's & 240 & 320 & 322 \\
Total BUSCO groups searched & & 4494 & \\
\hline
\end{tabular}

\subsection{Genome Analysis}

While the gene function of the predicted genes in each of the three genomes was assigned using Funannotate, the predicted proteome of each strain was run again through Eggnog-mapper v2.1.4-2. This yielded the following results, where for strain RA3a of the 8,951 predicted proteins, $86.7 \%$ could have a COG (Clusters of Orthologous Groups) category assigned; similarly, of the 8964 proteins predicted in strain RA5, 86.7\% could have COG categories assigned, and $86.2 \%$ of the 9124 predicted proteins from RA6 could be too.

The distribution of these predicted proteins across the COG categories is shown in Figure 4. Distribution of proteins across the categories did not differ significantly across any of the three genomes, and while the most frequently mapped category was "Function Unknown", of those that could be placed into a category of known function, the five most common in order of decreasing predicted protein count within the categories were "Intracellular trafficking, secretion, and vesicular transport", "Amino acid transport and metabolism", "Secondary metabolite biosynthesis, transport and catabolism", "Posttranslational modification, protein turnover, chaperones", and "Carbohydrate transport and metabolism". The presence of over 475 proteins associated with secondary metabolites in each genome is promising and these deserve further examinations, particularly in the context of the antagonistic activity of the fungal isolates against E. mallotivora and, potentially, other microorganisms. It is also interesting that no mobilome elements associated with transposons and prophages were detected, and less than 100 predicted proteins were identified in each genome that were associated with any of the following categories: "Extracellular structures", "Cell motility", "Nuclear structure", and "Defence mechanisms".

Figure 5 shows that the eggnog mapper was also able to assign gene ontology terms; often multiple terms are assigned to individual proteins, as well as enzyme commission numbers, a variety of matches to multiple KEGG databases, and also to BRITE hierarchies. A limited number of predicted proteins (no more than $2 \%$ in any genomes) were also associated with matches to the CAZy database of carbohydrate active enzymes, as well as matches to BiGG IDs. More promising was that around $85 \%$ of genes in each genome were matched to proteins in the pfam database. There was considerable overlap between these categories, however; most genes are close to identical across each of the three genomes. All data generated using eggnog mapper are included in the Dataset S1. 


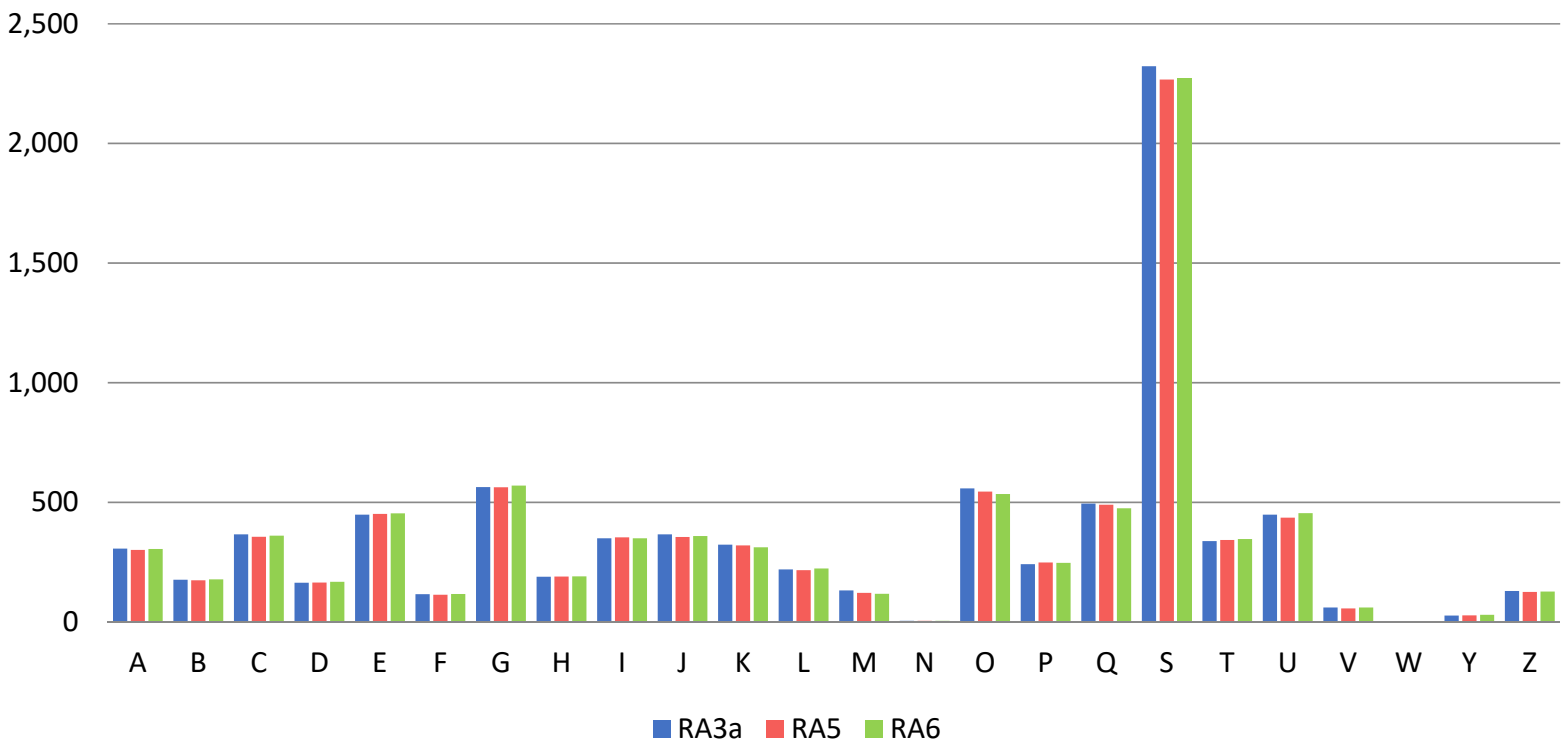

Figure 4. Distribution of predicted proteins in the three fungal isolates RA3a, RA5, and RA6 across the different COG categories. A: RNA processing and modification. B: Chromatin structure and dynamics. C: Energy production and conversion. D: Cell cycle control, cell division, chromosome partitioning. E: Amino acid transport and metabolism. F: Nucleotide transport and metabolism. G: Carbohydrate transport and metabolism. H: Coenzyme transport and metabolism. I: Lipid transport and metabolism. J: Translation, ribosomal structure. and biogenesis. K: Transcription. L: Replication, recombination. and repair. M: Cell wall/membrane/envelope biogenesis. N: Cell motility. O: Posttranslational modification, protein turnover, chaperones. P: Inorganic ion transport and metabolism. Q: Secondary metabolites biosynthesis, transport. and catabolism. S: Function unknown. T: Signal transduction mechanisms. U: Intracellular trafficking, secretion, and vesicular transport. V: Defense mechanisms. W: Extracellular structures. Y: Nuclear structure. Z: Cytoskeleton. The following returned no hits: R: General function prediction only; X: Mobilome- prophages, transposons.

\section{Eggnog Assignment}

10,000

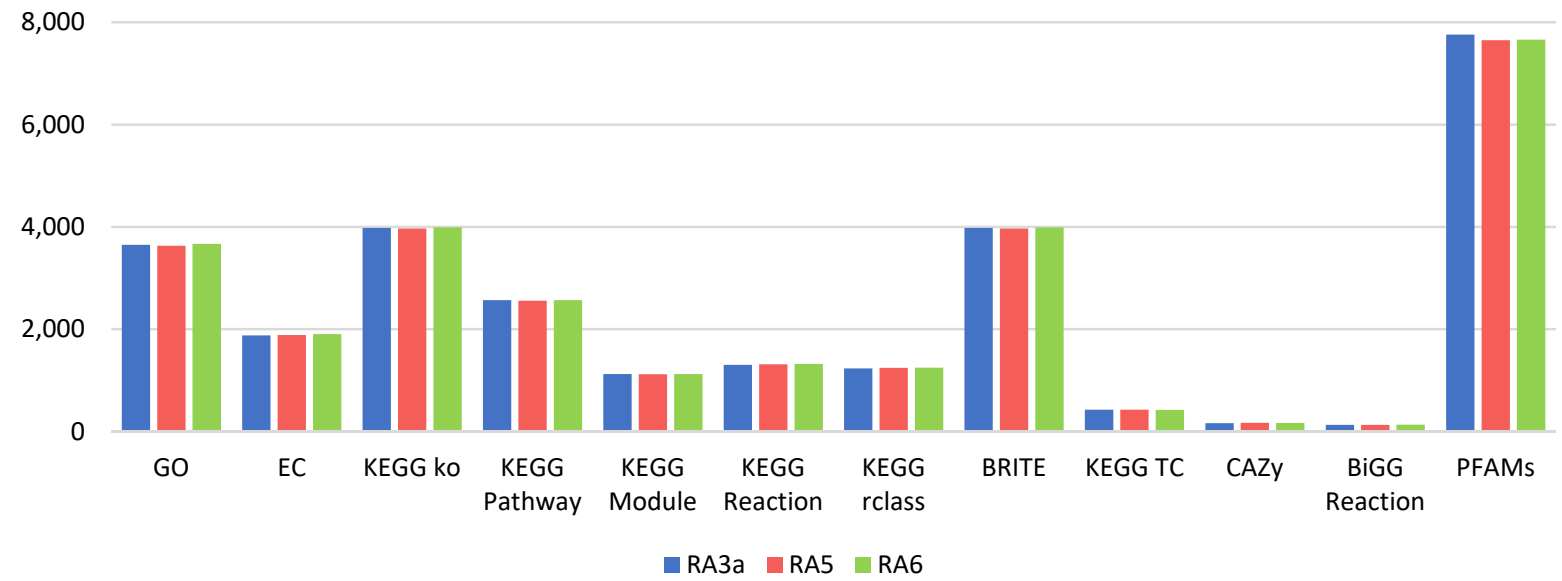

Figure 5. Assignment of predicted proteins in the three fungal isolates RA3a, RA5, and RA6 using eggnog mapper to multiple databases. 


\subsection{Comparative Genomics and Phylogenomic Analysis}

Pairwise comparison of genomic similarities between our isolates was performed by calculating the average nucleotide identity (ANI) values. The three isolates, RA3a, RA5, and RA6, showed high genomic similarities between each other (ANI value of 99\%) in addition to the T. koningiopsis POS7 isolate, which shared an ANI value of 96\% (Figure 6). Conversely, the three isolates showed lower genomic similarities with other Trichoderma spp. (79-89\% of ANI value). These results further confirm the identity of our isolates as belonging to the T. koningiopsis species.

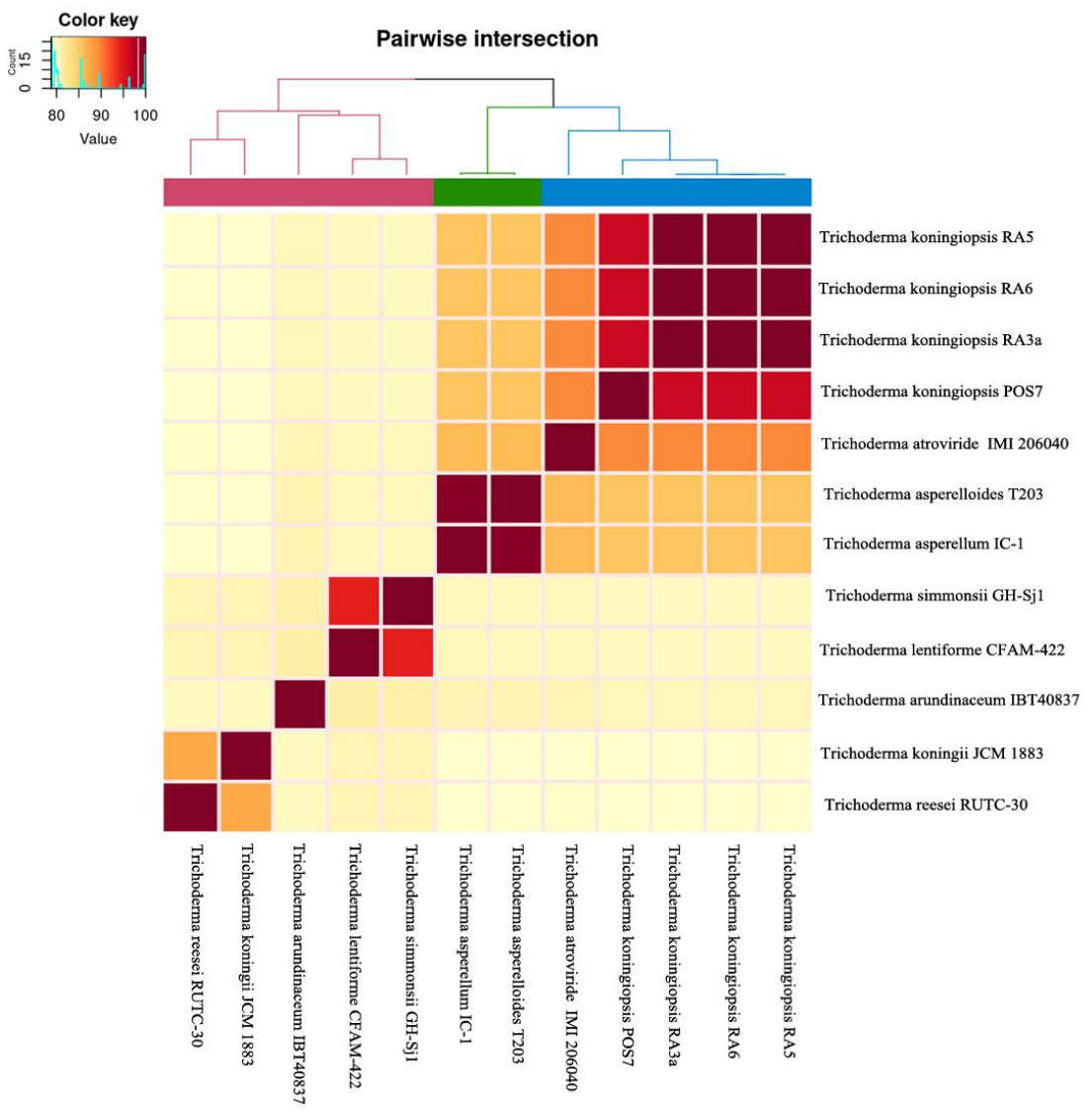

Figure 6. The ANI values based on the FastANI algorithm for Trichoderma spp. related genomes. The clustering was done based on a Euclidean distance matrix.

Further analysis using OrthoFinder suggested that there is a total of 12,270 orthogroups present among the predicted proteomes used in our analysis. Among that, a total of 3392 of the orthologous proteins exist as single-copy and alignment of their amino acids sequence was used for phylogenomic tree construction. The phylogenomic tree generated shows that the three isolates formed a distinct monophyletic group and shared a recent common ancestor within T. atroviride IMI206040 (Figure S2). The robustness of the phylogenomic tree generated was confirmed as all the branches showed $100 \%$ bootstrap values.

Next, the predicted protein sequences from our isolates were compared with each other using the OrthoVenn 2 web server. All the predicted protein sequences extracted from our genomes were further grouped into 9225 orthologous proteins. Among these, a total of 8245 protein groups were shared by all isolates. These proteins accounted for 86.64 (RA3a), 89.09 (RA5), and $89.00 \%$ (RA6) of the total orthologous protein group encoded in each genome (Figure S3). Therefore, OrthoVenn2 analysis confirmed that most of the proteins encoded for by the three isolates are shared. 


\subsection{Secondary Metabolite Clusters}

The whole genome sequences of the Trichoderma isolates RA3a, RA5, and RA6 were mined for putative biosynthetic gene clusters (BGCs) using AntiSMASH [54]. A total number of 124 clusters were identified across the three genomes; 43 BGCs were identified in isolate RA3a, 40 in isolate RA5, and 41 BGCs in isolate RA6. The strains varied in the putative classes they encode (Table 7 and Dataset S2). Non-ribosomal peptide synthetase (NRPS) clusters are the most dominant across the isolates followed by polyketide synthase (PKS) clusters, and Terpene and hybrid NRPS-PKS clusters. The number of BGCs from the sequenced fungal strains (RA3a, RA5, and RA6) was compared to the number of BGCs from other members of the Trichoderma genus (Figure 7), as predicted by AntiSMASH. This revealed that the fungal strains isolated in this study have the potential to be talented producers of polyketides and non-ribosomal peptide synthases, in line with other members of the Trichoderma genus.

Table 7. Biosynthetic gene clusters predicted through AntiSMASH analysis for the genomes of the Trichoderma isolates RA3a, RA5, and RA6.

\begin{tabular}{ccccccc}
\hline Fungal Strain & Total Clusters & NRPS-Like & PKS & Terpene & $\begin{array}{c}\text { Hybrid } \\
\text { NRPS/PKS }\end{array}$ & $\begin{array}{c}\text { Hybrid } \\
\text { PKS/Terpene }\end{array}$ \\
\hline $\begin{array}{c}\text { UKM-M-UW } \\
\text { RA3a }\end{array}$ & 43 & 17 & 14 & 7 & 4 & 1 \\
$\begin{array}{c}\text { UKM-M-UW } \\
\text { RA5 }\end{array}$ & 40 & 16 & 11 & 8 & 4 & 1 \\
$\begin{array}{c}\text { UKM-M-UW } \\
\text { RA6 }\end{array}$ & 41 & 17 & 12 & 7 & 4 & 1 \\
\hline
\end{tabular}

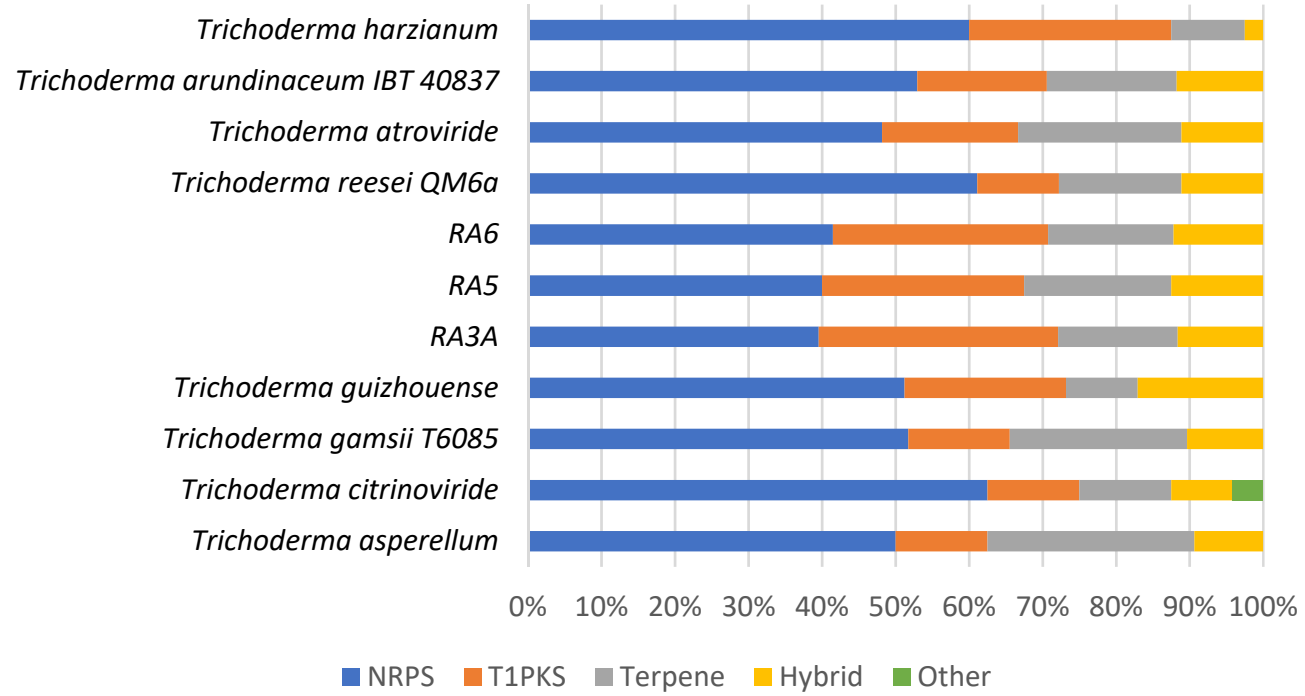

Figure 7. Comparison of the BGCs found in the genomes of the fungal strains RA3a, RA5, and RA6 with other members of the Trichoderma genus. BGC prediction was performed through AntiSMASH.

We then screened for clusters that were consistently present across the three strains, which could be indicative of their shared bioactivity against $E$. mallotivora. As predicted by AntiSMASH, we could find BGCs with low-to-high similarity to those for known bioactive metabolites, namely fusaric acid, naphthopyrone, neurosporin A, ascochlorin, and clavaric acid (Table S4 and Dataset S3). Further manual BlastP analysis of the putative neurosporin A BGC, revealed that this cluster may in fact code for the biosynthesis of a salicylaldehyderelated compound. This observation is based on the identification within the BGC of a hr-PKS megasynthase and tailoring enzymes, all showing high homology with genes of 
the vir gene cluster, which is involved in the biosynthesis of the antimicrobial compounds trichoxide and virensols from the biocontrol fungus T. virens [72] (Table S5 and Figure S4).

\section{Discussion}

Trichoderma spp. are easily culturable and generally considered to be harmless to humans and animals-except for T. longibrachiatum [73,74]. Members of this genus have been used extensively in agriculture as eco-friendly biological control agents as they are capable to control (or suppress) other microorganisms directly or indirectly $[37,38,75,76]$. It is reported that various Trichoderma spp. are effective biocontrol means against many fungal pathogens and some bacterial pathogens [77]. Previous works explored and applied the idea of using microbial species to control E. mallotivora [26-31]; nevertheless, the use of Trichoderma as a fungal antagonist against the PDD pathogen has not been reported. In this study, we demonstrated the potential of five Trichoderma strains to cause growth inhibition of E. mallotivora strain BT-MARDI. Trichoderma offers an advantage over many other microbes (especially bacteria) in terms of fast rhizosphere colonisation, involvement in the soil nutrient cycle, and excellent viability after an extended storage period ( $>12$ months), thus making the fungus more efficient and appealing to the farmers [78,79]. In addition to their antagonistic features against pathogens, some species of Trichoderma are even capable of inducing plant defence mechanisms, which could be another important advantage [80].

To further gain insights on the antagonism of our isolates, we performed wholegenome sequencing on three fast-growing Trichoderma strains that showed significant inhibition of E. mallotivora to aid in the elucidation of the metabolites that might play a role in this interaction. From the sequencing results, we believe that the annotated draft genomes we produced can be treated as full open reading frames. Mutations and evolutionary divergence can explain some of the fragmented BUSCO scores, and even well-conserved genes can still be lost in some lineages [81]. The large coverage of the long read nanopore sequencing allowed for a robust first draft genome to be created, with few fragments. However, nanopore read base calling remains less accurate than Illumina, around 95\% [82], and while modern base calling software harnessing neural networks are improving this, it is still necessary to polish, with higher accuracy, short read Illumina sequencing data to create a robust genome assembly, in order to remove the indels and miscalled bases present in nanopore reads that otherwise lead to frameshifts and fragmentation of genes.

The genus Trichoderma is a well-recognised group of filamentous fungi known for their production of secondary metabolites, especially as talented producers of bioactive peptides, polyketides, plant growth regulators, enzymes, siderophores, and other antibiotics [38,81,83], and has been credited for its biocontrol activity as antifungal and antibacterial. For example, peptaibols are a well-studied class of peptide natural products from Trichoderma, synthesised by NRPS modules, producing a linear peptide consisting of dialkylated amino acids, isovaline, amino isobutyric acid (Aib), an acetylated $\mathrm{N}$-terminus, and a C-terminal amino alcohol [38]. They are credited for their antimicrobial properties, as well as their ability to induce systemic resistance in plants against microbial invasion. Another major class of Trichoderma natural products with biocontrol activity are koninginins. This family of compounds were first isolated from T. koningii and exhibited antifungal activity $[38,84]$. Interestingly, koninginins have also been isolated from T. koningiopsis in other studies and are reported to exhibit antifungal properties against Fusarium spp., Plectosphaerella cucumerina, and Alternaria panax [85]. Prominent examples of polyketides isolated from Trichoderma spp. include pyrones and pyridines $[38,86]$. Considering the diversity of bioactive molecules isolated from the genus-for a report about Trichoderma natural products we refer the reader to the review by Shenouda and Cox [86] —and given the vast biosynthetic potential emerged from AntiSMASH analysis conducted in our study, the three Trichoderma strains (RA3a, RA5, and RA6) have high potential to produce bioactive molecules that will warrant their use as biocontrol agents against plant pathogens. Noteworthy, we have identified BGCs conserved across the three fungal isolates, including 
one for the biosynthesis of putative salicylaldehyde-related compounds, which are known for their antimicrobial properties, such as those that have been isolated from T. virens [72] and T. citrinum [87]. Heterologous expression and/or knockout of the salicylaldehyde BGC homologues from RA3a, RA5, and RA6 will be needed to reveal the structure of the corresponding metabolites and their potential role in the bioactivity of the fungal isolates.

The dogma of biosynthetic studies remains that many fungal biosynthetic clusters are silent under standard laboratory conditions, which makes their full exploitation challenging $[88,89]$. Advances in synthetic biology via heterologous expression or genome editing may help us uncover the biosynthetic potential of the gene clusters $[90,91]$.

\section{Conclusions}

In this study, we have isolated fungal strains from soil samples collected in the rhizosphere of healthy papaya trees from different locations in Peninsular Malaysia, with the aim to identify a potential biological control agent capable of suppressing E. mallotivora, the pathogen that is responsible for the ongoing PDD outbreak in Malaysia and surrounding countries. The three Trichoderma isolates, UKM-M-UW RA3a, UKM-M-UW RA5, and UKM-M-UW RA6, have shown significant inhibition of the growth of E. mallotivora from plate-based bioassays, and molecular identification allowed us to assign them to the $T$. koningiopsis species. Whole-genome sequencing was performed, thereby providing a platform for their biosynthetic exploitation, with the goal of linking secondary metabolites to biosynthetic gene clusters. Biosynthetic gene clusters homologous to those for known bioactive metabolites were identified and found to be conserved across the three isolates, opening the way for future exploration of the biosynthetic potential of these fungi. With the growing need for greener alternatives to chemical pesticides, the biosynthetic studies on natural products from Trichoderma spp. is expected to grow, which may give rise to a new generation of biocontrol agents with an enormous impact in the agrochemical sector.

Supplementary Materials: The following are available online at https: / www.mdpi.com/article/ 10.3390/jof8030246/s1, Table S1: Concentration of the extracted gDNA measured through Qubit. Figure S1: HMW genomic DNA of the three Trichoderma isolates. Table S2: Primers and PCR amplicon sizes for molecular identification of isolates. Table S3: Details on the number of predicted non-coding RNAs identified in each genome. Figure S2: Phylogenomic tree from alignment of 3392 single-copy orthologous proteins from selected Trichoderma spp. Figure S3: Shared and unique orthologous protein group among isolates sequenced in this study as inferred from OrthoVenn2 web server analysis. Table S4: Distribution of predicted BGCs found across the fungal genomes. Table S5: Putative salicylaldehyde cluster found across the three sequenced fungal genomes. Figure S4: Protein sequence comparison of the putative salicylaldehyde cluster found in the genome of strains RA6, RA5, and RA3a. Dataset S1: Genome analysis through eggnog mapper. Dataset S2: AntiSMASH analysis of genomes. Dataset S3: Details of secondary metabolite clusters conserved across the genomes of strains RA3a, RA5, and RA6.

Author Contributions: Conceptualization, H.B., F.A. and N.M.-A.; methodology, H.B., M.A.A., N.M.-A., A.-A.T., J.A.W., R.T.O., S.J. and F.A.; software, F.A., J.A.W., S.J., M.A.A. and R.T.O.; validation, H.B., F.A. and N.M.-A.; formal analysis, N.M.-A., J.A.W., H.B., S.J. and F.A.; investigation, N.M.-A., A.-A.T., H.B., J.A.W. and R.T.O.; resources, H.B., F.A.; data curation, J.A.W.; writing-original draft preparation, A.-A.T., N.M.-A. and R.T.O.; writing-review and editing, H.B., F.A., J.A.W., A.-A.T. and M.A.A.; visualization, J.A.W., R.T.O., S.J. and A.-A.T.; supervision, H.B. and F.A.; project administration, H.B. and F.A.; funding acquisition, F.A and H.B. All authors have read and agreed to the published version of the manuscript.

Funding: This research was jointly funded by Universiti Kebangsaan Malaysia (UKM) through a Geran Galakan Penyelidikan-Industri grant [GGPI-2016-002], and the University of Warwick through an International Partnership Award. F.A. was supported by a Leverhulme Trust Early Career Fellowship [ECF-2018-691] and by a UKRI Future Leaders Fellowship [MR/V022334/1]. J.A.W. was supported by scholarship from the the Engineering and Physical Sciences Research Council and the Biotechnology and Biological Sciences Research Council [EP/L016494/1] through the Centre for Doctoral Training in Synthetic Biology (SynBioCDT). 


\section{Institutional Review Board Statement: Not applicable.}

Informed Consent Statement: Not applicable.

Data Availability Statement: The genome sequences generated in this study were submitted to GenBank. BioSample metadata is publicly available in the NCBI BioSample database (http:// www.ncbi.nlm.nih.gov/biosample/, last accessed on 25 January 2022) under accession numbers SAMN23731967, SAMN23731968, and SAMN23731969 for strains RA3a, RA5, and RA6 respectively. The annotated genomes are publicly available in the NCBI Genbank database (https:/ / www.ncbi.nlm. nih.gov/genbank/, last accessed on 25 January 2022) under accession numbers JAJPEM000000000, JAJPEL000000000, and JAJPEK000000000 for strains RA3a, RA5, and RA6 respectively. The results of the StructRNAfinder analysis are publicly available at https:/ / osf.io/vsbc2/ (last accessed on 25 January 2022).

Acknowledgments: The authors would like to acknowledge Maathavi Kannan and Iqbal M. Noor for their assistance in the laboratory and fieldworks.

Conflicts of Interest: The authors declare no conflict of interest.

\section{References}

1. FAOSTAT (Food and Agriculture Organisation of the United Nations Statistics Division). Available online: https://www.fao.org/ 3/ca5688en/CA5688EN.pdf (accessed on 20 July 2021).

2. Maktar, N.H.; Kamis, S.; Mohd Yusof, F.Z.; Hussain, N.H. Erwinia papayae causing papaya dieback in Malaysia. Plant Pathol. 2008, 57, 774. [CrossRef]

3. Mat Amin, N.; Bunawan, H.; Ahmad Redzuan, R.; Jaganath, I.B.S. Erwinia Mallotivora sp., a new pathogen of papaya (Carica papaya) in Peninsular Malaysia. Int. J. Mol. Sci. 2010, 12, 39-45. [CrossRef] [PubMed]

4. Ahmad Redzuan, R.; Abu Bakar, N.; Rozano, L.; Badrun, R.; Mat Amin, N.; Mohd Raih, M.F. Draft genome sequence of Erwinia mallotivora BT-MARDI, causative agent of papaya dieback disease. Genome Announc. 2014, 2, e00375-14. [CrossRef]

5. Supian, S.; Saidi, N.B.; Wee, C.-Y.; Abdullah, M.P. Antioxidant-mediated response of a susceptible papaya cultivar to a compatible strain of Erwinia mallotivora. Physiol. Mol. Plant Pathol. 2017, 98, 37-45. [CrossRef]

6. Noor Shahida, Y.; Awang, Y.; Sijam, K.; Noriha, M.A.; Satar, M.G.M. Biochemical changes and leaf photosynthesis of Erwinia mallotivora infected papaya (Carica papaya) aeedlings. Am. J. Plant Physiol. 2016, 11, 12-22. [CrossRef]

7. Pathania, N.; Justo, V.; Magdalita, P.; de la Cueva, F.; Herradura, L.; Waje, A.; Lobres, A.; Cueto, A.; Dillon, N.; Vawdrey, L.; et al. Integrated Disease Management Strategies for the Productive, Profitable and Sustainable Production of High Quality Papaya Fruit in the Southern Philippines and Australia—Final Report. Available online: https:/ /www.aciar.gov.au/publication/technicalpublications/integrated-disease-management-strategies-productive-profitable-and-sustainable (accessed on 20 July 2021).

8. Mohd Said, N.A.; Abu Bakar, N.; Lau, H.Y. Label-free detection of Erwinia mallotivora DNA for papaya dieback disease using electrochemical impedance spectroscopy approach. ASM Sci. J. 2020, 4, 1-8.

9. Ramachandran, K.; Manaf, U.A.; Zakaria, L. Molecular characterization and pathogenicity of Erwinia spp. associated with pineapple [Ananas comosus (L.) Merr.] and papaya (Carica papaya L.). J. Plant Prot. Res. 2015, 55, 396-404. [CrossRef]

10. Bunawan, H.; Baharum, S.N. Papaya dieback in Malaysia: A step towards a new insight of disease resistance. Iran J. Biotechnol. 2015, 13, 1-2. [CrossRef]

11. Mohd Khairil, J.; Muhammad Munzir, M. Experiences in managing bacterial dieback disease of papaya in Malaysia. Acta Hortic. 2014, 1022, 125-132. [CrossRef]

12. Suharjo, R.; Oktaviana, H.A.; Aeny, T.N.; Ginting, C.; Wardhana, R.A.; Nugroho, A.; Ratdiana, R. Erwinia mallotivora is the causal agent of papaya bacterial crown rot disease in Lampung Timur, Indonesia. Plant Prot. Sci. 2021, 57, 122-133. [CrossRef]

13. Hanagasaki, T.; Yamashiro, M.; Gima, K.; Takushi, T.; Kawano, S. Characterization of Erwinia sp. causing black rot of papaya (Carica papaya) first recorded in Okinawa Main Island, Japan. Plant Pathol. 2021, 70, 932-942. [CrossRef]

14. Wee, C.Y.; Muhammad Hanam, H.; Mohd Waznul Adly, M.Z.; Khairun, H.N. Expression of defense-related genes in papaya seedling infected with Erwinia mallotivora using real-time PCR. J. Trop. Agric. Fd. Sci. 2014, 42, 73-82.

15. Hamid, M.H.; Rozano, L.; Chien Yeong, W.; Abdullah, J.O.; Saidi, N.B. Analysis of MAP kinase MPK4/MEKK1/MKK genes of Carica papaya L. comparative to other plant homologues. Bioinformation 2017, 13, 31-41. [CrossRef] [PubMed]

16. Juri, N.M.; Samsuddin, A.F.; Abdul-Murad, A.M.; Tamizi, A.A.; Shaharuddin, N.A.; Abu-Bakar, N. Discovery of pathogenesis related and effector genes of Erwinia mallotivora in Carica papaya (Eksotika I) seedlings via transcriptomic analysis. Int. J. Agric. Biol. 2020, 23, 1021-1032. [CrossRef]

17. Juri, N.M.; Samsuddin, A.F.; Abdul-Murad, A.M.; Tamizi, A.A.; Hassan, M.A.; Abu-Bakar, N. In silico analysis and functional characterization of FHUB, a component of Erwinia mallotivora ferric hydroxamate uptake system. J. Teknol. 2020, 82, 83-90. [CrossRef]

18. Abu-Bakar, N.; Juri, N.M.; Abu-Bakar, R.A.H.; Sohaime, M.Z.; Badrun, R.; Sarip, J.; Hassan, M.A.; Ahmad, K. Recombinant protein foliar application activates systemic acquired resistance and increases tolerance against papaya dieback disease. Asian $J$. Agric. Rural Dev. 2021, 11, 1-9. [CrossRef] 
19. Abu Bakar, N.S.; Saidi, N.B.; Rozano, L.; Abdullah, M.P.; Supian, S. In-silico characterization and expression analysis of NB-ARC genes in response to Erwinia mallotivora in Carica papaya. Sains Malays. 2021, 50, 2591-2602. [CrossRef]

20. Tamizi, A.-A.; Abu-Bakar, N.; Samsuddin, A.-F.; Rozano, L.; Ahmad-Redzuan, R.; Abdul-Murad, A.-M. Characterisation and mutagenesis study of an alternative sigma factor gene $(h r p L)$ from Erwinia mallotivora reveal its central role in papaya dieback disease. Biology 2020, 9, 323. [CrossRef] [PubMed]

21. Sekeli, R.; Hamid, M.H.; Razak, R.A.; Wee, C.Y.; Ong-Abdullah, J. Malaysian Carica papaya L. var. Eksotika: Current research strategies fronting challenges. Front. Plant Sci. 2018, 9, 1380. [CrossRef]

22. Sekeli, R.; Nazaruddin, N.H.; Tamizi, A.A.; Mat Amin, N.; Wee, C.Y.; Sarip, J.; Abdullah, N.; Saidi, N.I.; Abdul Razak, R.; Zulkifli, Z. Enhancing Eksotika papaya resistance to dieback disease through quorum quenching. J. Trop. Plant Physiol. $2019,11,1-9$.

23. Mohd-Azhar, H.; Sarip, J.; Ghazali, N.F.; Mohd Razikin, M.Z.; Mariatulqabtiah, A.R. Tolerance level of grafted papaya plants against papaya dieback disease. Malays. Appl. Biol. 2021, 50, 95-103.

24. Mohd Azhar, H.; Johari, S.; Nur Sulastri, J.; Razali, M.; Muhammad Zulfa, M.R.; Noor Faimah, G.; Mariatulqabtiah, A.R. Field performance of selected papaya hybrids for tolerance to dieback disease. J. Trop. Agric. Fd. Sci. 2020, 48, 25-33.

25. Sarip, J.; Radzuan, S.M.; Ghazali, M.F.; Norasiah, R. Viorica: A Papaya Variety Highly Tolerant to Dieback Disease. In Proceedings of the International Congress of the Malaysian Society for Microbiology, Penang, Malaysia, 7-10 December 2015.

26. Mat Amin, N.; Nor Rahim, M.Y.; Ahmad Redzuan, R.; Tamizi, A.A.; Bunawan, H. Acyl homoserine lactonase genes from Bacillus species isolated from tomato rhizosphere soil in Malaysia. Res. J. Appl. Sci. 2016, 11, 656-659.

27. Mat Amin, N.; Nor Rahim, M.Y.; Ahmad Redzuan, R.; Tamizi, A.A.; Bunawan, H. Quorum quenching bacteria isolated from rice and tomato rhizosphere soil in Malaysia. J. Appl. Biol. Sci. 2016, 10, 61-63.

28. Blog Rasmi MARDI. Available online: https://blogmardi.wordpress.com/2017/08/02/ (accessed on 6 December 2021).

29. All Cosmos. Available online: https:/ / allcosmos.com/services-view/dieback-buster-95-2dbottle/ (accessed on 6 December 2021).

30. Rivarez, M.P.S.; Parac, E.P.; Dimasingkil, S.F.M.; Magdalita, P.M. Influence of native endophytic bacteria on the growth and bacterial crown rot tolerance of papaya (Carica papaya). Eur. J. Plant Pathol. 2021, 161, 593-606. [CrossRef]

31. Mohd Taha, M.D.; Mohd Jaini, M.F.; Saidi, N.B.; Abdul Rahim, R.; Md Shah, U.K.; Mohd Hashim, A. Biological control of Erwinia mallotivora, the causal agent of papaya dieback disease by indigenous seed-borne endophytic lactic acid bacteria consortium PLoS ONE 2019, 14, e0224431. [CrossRef]

32. Mukhopadhyay, R.; Kumar, D. Trichoderma: A beneficial antifungal agent and insights into its mechanism of biocontrol potential. Egypt J. Biol. Pest Control 2020, 30, 133. [CrossRef]

33. Harman, G.E. Overview of mechanisms and uses of Trichoderma spp. Phytopathology 2006, 96, 190-194. [CrossRef]

34. Keswani, C.; Mishra, S.; Sarma, B.K.; Singh, S.P.; Singh, H.B. Unraveling the efficient applications of secondary metabolites of various Trichoderma spp. Appl. Microbiol. Biotechnol. 2014, 98, 533-544. [CrossRef] [PubMed]

35. Contreras-Cornejo, H.A.; Macías-Rodríguez, L.; Del-Val, E.; Larsen, J. Ecological functions of Trichoderma spp. and their secondary metabolites in the rhizosphere: Interactions with plants. FEMS Microbiol. Ecol. 2016, 92, fiw036. [CrossRef] [PubMed]

36. Bitas, V.; Kim, H.S.; Bennett, J.W.; Kang, S. Sniffing on microbes: Diverse roles of microbial volatile organic compounds in plant health. Mol. Plant Microbe Interact. 2013, 26, 835-843. [CrossRef]

37. Guo, Y.; Ghirardo, A.; Weber, B.; Schnitzler, J.P.; Benz, J.P.; Rosenkranz, M. Trichoderma species differ in their volatile profiles and in antagonism toward ectomycorrhiza Laccaria bicolor. Front. Microbiol. 2019, 10, 891. [CrossRef]

38. Khan, R.A.A.; Najeeb, S.; Hussain, S.; Xie, B.; Li, Y. Bioactive secondary metabolites from Trichoderma spp. against phytopathogenic fungi. Microorganisms 2020, 8, 817. [CrossRef] [PubMed]

39. Rush, T.A.; Shrestha, H.K.; Gopalakrishnan Meena, M.; Spangler, M.K.; Ellis, J.C.; Labbé, J.L.; Abraham, P.E. Bioprospecting Trichoderma: A systematic roadmap to screen genomes and natural products for biocontrol applications. Front. Fungal Biol. 2021, 2, 716511. [CrossRef]

40. Vargas Gil, S.; Pastor, S.; Marcha, G.J. Quantitative isolation of biocontrol agents Trichoderma spp., Gliocladium spp. and actinomycetes from soil with culture media. Microbiol. Res. 2009, 164, 196-205. [CrossRef] [PubMed]

41. Zhang, K.; Yuan-Ying, S.; Lei, C. An optimized protocol of single spore isolation for fungi. Cryptogam. Mycol. 2013, 34, 349-356. [CrossRef]

42. Magaldi, S.; Mata-Essayag, S.; Hartung de Capriles, C.; Perez, C.; Colella, M.T.; Olaizola, C.; Ontiveros, Y. Well diffusion for antifungal susceptibility testing. Int. J. Infect. Dis. 2004, 8, 39-45. [CrossRef]

43. Valgas, C.; de Souza, S.M.; Smânia, E.F.A.; Smânia, A., Jr. Screening methods to determine antibacterial activity of natural products. Braz. J. Microbiol. 2007, 38, 369-380. [CrossRef]

44. Kopchinskiy, A.; Komon, M.; Kubicek, C.P.; Druzhinina, I.S. TrichoBLAST: A multilocus database for Trichoderma and Hypocrea identifications. Mycol. Res. 2005, 109, 658-660. [CrossRef] [PubMed]

45. Altschul, S.F.; Gish, W.; Miller, W.; Myers, E.W.; Lipman, D.J. Basic local alignment search tool. J. Mol. Biol. 1990, 215 , 403-410. [CrossRef]

46. Kolmogorov, M.; Yuan, J.; Lin, Y.; Pevzner, P.A. Assembly of long, error-prone reads using repeat graphs. Nat. Biotechnol. 2019, 37, 540-546. [CrossRef] [PubMed]

47. Li, H. Minimap2: Pairwise alignment for nucleotide sequences. Bioinformatics 2018, 34, 3094-3100. [CrossRef]

48. Vaser, R.; Sović, I.; Nagarajan, N.; Šikić, M. Fast and accurate de novo genome assembly from long uncorrected reads. Genome Res. 2017, 27, 737-746. [CrossRef] 
49. Langmead, B.; Salzberg, S.L. Fast gapped-read alignment with Bowtie 2. Nat. Methods 2021, 9, 357-359. [CrossRef]

50. Walker, B.J.; Abeel, T.; Shea, T.; Priest, M.; Abouelliel, A.; Sakthikumar, S.; Cuomo, C.A.; Zeng, Q.; Wortman, J.; Young, S.K.; et al. Pilon: An integrated tool for comprehensive microbial variant detection and genome assembly improvement. PLoS ONE 2014, 9, e112963. [CrossRef]

51. Seppey, M.; Manni, M.; Zdobnov, E.M. BUSCO: Assessing genome assembly and annotation completeness. Methods Mol. Biol. 2019, 1962, 227-245. [CrossRef] [PubMed]

52. Palmer, J.M.; Stajich, J. Funannotate v1.8.1: Eukaryotic Genome Annotation. Available online: https://zenodo.org/ record/4054 262\#.YhxHjOpBxPY (accessed on 20 August 2021).

53. Käll, L.; Krogh, A.; Sonnhammer, E.L.L. A combined transmembrane topology and signal peptide prediction method. J. Mol. Biol. 2004, 338, 1027-1036. [CrossRef]

54. Blin, K.; Shaw, S.; Steinke, K.; Villebro, R.; Ziemert, N.; Lee, S.Y.; Medema, M.H.; Weber, T. antiSMASH 5.0: Updates to the secondary metabolite genome mining pipeline. Nucleic Acids Res. 2019, 47, W81-W87. [CrossRef]

55. Burge, S.W.; Daub, J.; Eberhardt, R.; Tate, J.; Barquist, L.; Nawrocki, E.P.; Eddy, S.R.; Gardner, P.P.; Bateman, A. Rfam 11.0: 10 years of RNA families. Nucleic Acids Res. 2013, 41, D226-D232. [CrossRef]

56. Arias-Carrasco, R.; Vásquez-Morán, Y.; Nakaya, H.I.; Maracaja-Coutinho, V. StructRNAfinder: An automated pipeline and web server for RNA families prediction. BMC Bioinform. 2018, 19, 55. [CrossRef]

57. Griffiths-Jones, S.; Moxon, S.; Marshall, M.; Khanna, A.; Eddy, S.R.; Bateman, A. Rfam: Annotating non-coding RNAs in complete genomes. Nucleic Acids Res. 2005, 33, D121-D124. [CrossRef] [PubMed]

58. Jain, C.; Rodriguez-R, L.M.; Phillippy, A.M.; Konstantinidis, K.T.; Aluru, S. High throughput ANI analysis of 90K prokaryotic genomes reveals clear species boundaries. Nat. Commun. 2018, 9, 5114. [CrossRef] [PubMed]

59. Khan, A.; Mathelier, A. Intervene: A tool for intersection and visualization of multiple gene or genomic region sets. BMC Bioinform. 2017, 18, 287. [CrossRef] [PubMed]

60. Emms, D.M.; Kelly, S. OrthoFinder: Phylogenetic orthology inference for comparative genomics. Genome Biol. $2019,20,238$. [CrossRef]

61. Katoh, K.; Standley, D.M. MAFFT multiple sequence alignment software version 7: Improvements in performance and usability. Mol. Biol. Evol. 2013, 30, 772-780. [CrossRef]

62. Nguyen, L.T.; Schmidt, H.A.; Von Haeseler, A.; Minh, B.Q. IQ-TREE: A fast and effective stochastic algorithm for estimating maximum-likelihood phylogenies. Mol. Biol. Evol. 2015, 32, 268-274. [CrossRef]

63. Letunic, I.; Bork, P. Interactive Tree of Life (iTOL) v4: Recent updates and new developments. Nucleic Acids Res. 2019, 47, W256-W259. [CrossRef] [PubMed]

64. Xu, L.; Dong, Z.; Fang, L.; Luo, Y.; Wei, Z.; Guo, H.; Zhang, G.; Gu, Y.Q.; Coleman-Derr, D.; Xia, Q.; et al. OrthoVenn2: A web server for whole-genome comparison and annotation of orthologous clusters across multiple species. Nucleic Acids Res. 2019, 47, W52-W58. [CrossRef]

65. Cai, F.; Druzhinina, I.S. In honor of John Bissett: Authoritative guidelines on molecular identification of Trichoderma. Fungal Divers. 2021, 107, 1-69. [CrossRef]

66. Schoch, C.L.; Seifert, K.A.; Huhndorf, S.; Robert, V.; Spouge, J.L.; Levesque, C.A.; Chen, W.; Bolchacova, E.; Voigt, K.; Crous, P.W.; et al. Nuclear ribosomal internal transcribed spacer (ITS) region as a universal DNA barcode marker for Fungi. Proc. Natl. Acad. Sci. USA 2012, 109, 6241-6246. [CrossRef]

67. Druzhinina, I.; Kubicek, C.P. Species concepts and biodiversity in Trichoderma and Hypocrea: From aggregate species to species clusters? J. Zhejiang Univ. Sci. B 2005, 6, 100-112. [CrossRef]

68. Liu, Y.J.; Whelen, S.; Hall, B.D. Phylogenetic relationships among ascomycetes: Evidence from an RNA polymerse II subunit. Mol. Biol. Evol. 1999, 16, 1799-1808. [CrossRef] [PubMed]

69. Kubicek, C.P.; Steindorff, A.S.; Chenthamara, K.; Manganiello, G.; Henrissat, B.; Zhang, J.; Cai, F.; Kopchinskiy, A.G.; Kubicek, E.M.; Kuo, A.; et al. Evolution and comparative genomics of the most common Trichoderma species. BMC Genomics 2019, $20,485$. [CrossRef] [PubMed]

70. Druzhinina, I.S.; Kopchinskiy, A.G.; Kubicek, E.M.; Kubicek, C.P. A complete annotation of the chromosomes of the cellulase producer Trichoderma reesei provides insights in gene clusters, their expression and reveals genes required for fitness. Biotechnol. Biofuels 2016, 9, 75. [CrossRef] [PubMed]

71. El Komy, M.H.; Saleh, A.A.; Eranthodi, A.; Molan, Y.Y. Characterization of novel Trichoderma asperellum isolates to select effective biocontrol agents against tomato Fusarium wilt. Plant Pathol. J. 2015, 31, 50-60. [CrossRef]

72. Liu, L.; Tang, M.-C.; Tang, Y. Fungal Highly Reducing Polyketide Synthases Biosynthesize Salicylaldehydes That Are Precursors to Epoxycyclohexenol Natural Products. J. Am. Chem. Soc. 2019, 141, 19538-19541. [CrossRef]

73. Munoz, F.M.; Demmler, G.J.; Travis, W.R.; Ogden, A.K.; Rossmann, S.N.; Rinaldi, M.G. Trichoderma longibrachiatum infection in a pediatric patient with aplastic anemia. J. Clin. Microbiol. 1997, 35, 499-503. [CrossRef] [PubMed]

74. Sautour, M.; Chrétien, M.L.; Valot, S.; Lafon, I.; Basmaciyana, L.; Legouge, C.; Verrier, T.; Gonssaud, B.; Abou-Hanna, H.; Dalle, F.; et al. First case of proven invasive pulmonary infection due to Trichoderma longibrachiatum in a neutropenic patient with acute leukemia. J. Mycol. Med. 2018, 28, 659-662. [CrossRef] [PubMed]

75. Waghunde, R.R.; Shelake, R.M.; Sabalpara, A.N. Trichoderma: A significant fungus for agriculture and environment. Afr. J. Agric. Res. 2016, 11, 1952-1965. [CrossRef] 
76. Zin, N.A.; Badaluddin, N.A. Biological functions of Trichoderma spp. for agriculture applications. Ann. Agric. Sci. 2020, 65, 168-178. [CrossRef]

77. Thapa, S.; Rai, N.; Limbu, A.K.; Joshi, A. Impact of Trichoderma sp. in agriculture: A mini-review. J. Biol. Today's World 2020, 9, 227.

78. Singh, A.; Sarma, B.K.; Singh, H.B.; Upadhyay, R.S. Trichoderma: A silent worker of plant rhizosphere. In Biotechnology and Biology of Trichoderma, 1st ed.; Gupta, V.K., Schmoll, M., Herrera-Estrella, A., Upadhyay, R.S., Druzhinina, I., Tuohy, M.G., Eds.; Elsevier: Amsterdam, The Netherlands, 2014; pp. 533-542.

79. Stocco, M.; Mónaco, C.; Cordo, C. A comparison of preservation methods for Trichoderma harzianum cultures. Rev. Iberoam. Micol. 2010, 27, 213. [CrossRef]

80. Sood, M.; Kapoor, D.; Kumar, V.; Sheteiwy, M.S.; Ramakrishnan, M.; Landi, M.; Araniti, F.; Sharma, A. Trichoderma: The "secrets" of a multitalented biocontrol agent. Plants 2020, 9, 762. [CrossRef]

81. Simão, F.A.; Waterhouse, R.M.; Ioannidis, P.; Kriventseva, E.V.; Zdobnov. E.M. BUSCO: Assessing genome assembly and annotation completeness with single-copy orthologs. Bioinformatics 2015, 31, 3210-3212. [CrossRef] [PubMed]

82. Zhang, Y.Z.; Akdemir, A.; Tremmel, G.; Imoto, S.; Miyano, S.; Shibuya, T.; Yamaguchi, R. Nanopore basecalling from a perspective of instance segmentation. BMC Bioinform. 2020, 21, 136. [CrossRef]

83. Li, M.F.; Li, G.H.; Zhang, K.Q. Non-volatile metabolites from Trichoderma spp. Metabolites 2019, 9, 58. [CrossRef]

84. Parker, S.R.; Cutler, H.G.; Schreiner, P.R. Koninginin C: A biologically active natural product from Trichoderma koningii. Biosci. Biotechnol. Biochem. 1995, 59, 1126-1127. [CrossRef]

85. Liu, K.; Yang, Y.B.; Chen, J.L.; Miao, C.P.; Wang, Q.; Zhou, H.; Chen, Y.W.; Li, Y.Q.; Ding, Z.T.; Zhao, L.X. Koninginins N-Q, polyketides from the endophytic fungus Trichoderma koningiopsis harbored in Panax notoginseng. Nat. Prod. Bioprospect. 2016, 6, 49-55. [CrossRef] [PubMed]

86. Shenouda, M.L.; Cox, R.J. Molecular methods unravel the biosynthetic potential of Trichoderma species. RSC Adv. 2021, 11, 3622-3635. [CrossRef]

87. Berkaew, P.; Soonthornchareonnon, N.; Salasawadee, K.; Chanthaket, R.; Isaka, M. Aurocitrin and Related Polyketide Metabolites from the Wood-Decay Fungus Hypocrea sp. BCC 14122. J. Nat. Prod. 2008, 71, 902-904. [CrossRef] [PubMed]

88. Hyde, K.D.; Xu, J.; Rapior, S.; Jeewon, R.; Lumyong, S.; Niego, A.G.T.; Abeywickrama, P.D.; Aluthmuhandiram, J.V.S.; Brahamanage, R.S.; Brooks, S.; et al. The amazing potential of fungi: 50 ways we can exploit fungi industrially. Fungal Divers. 2019, 97, 1-136. [CrossRef]

89. Kjærbølling, I.; Mortensen, U.H.; Vesth, T.; Andersen, M.R. Strategies to establish the link between biosynthetic gene clusters and secondary metabolites. Fungal Genet. Biol. 2019, 130, 107-121. [CrossRef]

90. Alberti, F.; Foster, G.D.; Bailey, A.M. Natural products from filamentous fungi and production by heterologous expression. Appl. Microbiol. Biotechnol. 2017, 101, 493-500. [CrossRef] [PubMed]

91. Harvey, C.J.B.; Tang, M.; Schlecht, U.; Horecka, J.; Fischer, C.R.; Lin, H.C.; Li, J.; Naughton, B.; Cherry, J.; Miranda, M.; et al. HEx: A heterologous expression platform for the discovery of fungal natural products. Sci. Adv. 2018, 4, eaar5459. [CrossRef] [PubMed] 